I.М. ЯСЮК

Луиьький національний технічний університет

\title{
ОГЛЯД ВИДІВ ФІБР ДЛЯ ДИСПЕРСНО-АРМОВАНИХ БЕТОНІВ
}

И.Н. ЯСЮК

Луиякий национальный технический университет

\section{ОБЗОР ВИДОВ ФИБРЫ ДЛЯ ДИСПЕРСНО-АРМИРОВАННЫХ БЕТОНОВ}

I. YASYUK

Lutsk National Technical University

\section{OVERVIEW OF THE TYPES OF FIBERS FOR DISPERSION- REINFORCED CONCRETE}

\section{https://doi.org/10.36910/6775-2310-5283-2018-11-21}

Мета. Проаналізувати види фібр для дисперсно-армованих бетонів, щзо сьогодні представлені на ринку будівельних матеріалів. Охарактеризувати їх недоліки та переваги. Особливу увагу приділити сталевим фібрам, що застосовуються під час виготовлення сталефібробетону.

Методика. Під час проведення дослідження використовувались передбачені діючими державними стандартами методи, які дозволяють визначити механічні властивості залізобетонних та сталефібробетонних конструкиій.

Результати. Проаналізувавши сфери застосування залізобетонних конструкиій під час будівництва інженерних споруд, рекомендовано застосовувати, під час їх виготовлення, дисперсно армовані бетони. Під час проведення досліджень встановлено, що при введені в бетон сталевих фібр, значно збільшується його жорсткість, що в свою чергу призводить до підвищення деформативності від дії навантажень та тріщиностійкості сталефібро-бетону, як матеріалу. В статті розглянуто різні види фібрового армування бетону. Представлено коротку характеристику кожної з видів фібр, щуо представлені на ринку будівельних матеріалів в Україні.

Наукова новизна. Описано доцільність дисперсного армування бетону під час виготовлення інженерних конструкиій. Зроблено висновки щьоо недостатнього вивчення методів розрахунку фібробетону при різних впливах.

Практична значимість. Результати проведених наукових досліджень можуть бути використані під час проектування та будівниџтва дорожньо-транспортних споруд із сталефібробетону на автомобільних дорогах, що піддаються дї значних динамічних впливів.

Ключові слова: залізобетон, сталефібробетон, СФБ, фібра, водовідведення, лоток, міциність, тріщиноостійкість. 
Постановка проблеми у загальному вигляді і їі зв’язок 3 важливими науковими та практичними завданнями. Під час експлуатації залізобетонних елементів та конструкцій в дорожньому будівництві під впливом погодно-кліматичних факторів та вібраційних коливань (повторних навантажень) від руху транспортних засобів на їх поверхні відбувається руйнування, що призводить до утворення тріщин, вибоїн, вилущування бетону, руйнування захисного шару бетону та ін.

Аналіз останніх досліджень, у яких започатковано вирішення проблеми. Введення фібр в бетон i їх дисперсне розташування в обсязі матеріалу дозволило сформулювати поняття композиційного матеріалу на основі бетонної (цементної) матриці. Одним 3 найбільш перспективних варіантів поліпшення якості матеріалів, є їх доповнення новими сполучними компонентами, наприклад міцними волокнами, які роблять вихідний матеріал міцніше. Армований фібрами бетон в кілька разів перевершує якісні характеристики звичайного бетону. Однак недостатня вивченість стійкості волокон в цементній матриці бетону обмежує області і обсяг застосування фібробетону в будівництві, незважаючи на те, що використання неметалічних волокон виключає ряд проблем, пов'язаних з корозією сталевих фібр. Спектр областей застосування фібробетону дуже широкий. I кожна з цих областей пред'являє до фібробетонних конструкцій свої специфічні вимоги, як по механічним, так і по реологічним властивостями.

Цілі статті. Виконати порівняльний аналіз характеристик різних видів фібрового армування за варіаційними показниками.

Об’єктом дослідження є фібра для дисперсно-армованих бетонів.

Виклад основного матеріалу дослідження 3 повним обгрунтуванням отриманих наукових результатів. Сьогодні бетон є самим масовим штучним матеріалом, що продукує людство. В класичному бетоні крім високих міцністних механічних властивостей є й ряд недоліків, над усуненням яких працює багато науковців-будівельників. Одним із перспективних конструкційних матеріалів, що дає змогу компенсувати такі недоліки бетону, як низьку міцність і трищиностійкість під час розтягування, високу крихкість, $\epsilon$ дисперсно-армовані бетони - фібробетони. Наявність армуючих волокон (фібри) у бетоні за умови їх оптимального вмісту підвищує щільність, однорідність та зменшує ризики тріщиноутворення. А також дає змогу прогнозувати вищу витривалість і довговічність цементного бетону, підвищує його морозостійкість на $12 \%$, водонепроникність на 50-100 \%, ударостійкість на $30 \%$, стирання зменшується на 40-44\% [1]. Одним із видів фібробетонів 3 підвищеними механічними властивостями є сталефібробетон. 
Сталефібробетон (СФБ) - бетон, що армований під час його виготовлення рівномірно розподіленими в об'ємі сталевими фібрами.

В Україні проводяться дослідження застосування СФБ під час будівництва автомобільних доріг [2-5], які експлуатуються в умовах впливу значних динамічних навантажень. Варто відмітити, що перспективна інтенсивність руху на дорогах I-a та I-б категорії приймається в розрахунках понад 10000 транспортних засобів на добу. Пропускна здатність окремих автомобільних доріг державного та міжнародного значення в Україні навіть перевищує ці стандарти - зокрема дорога Київ-Бориспіль має пропускну здатність 40 тис. авт/добу. Величезні потоки транспорту проходять через січення доріг такого класу $\mathrm{i}$ створюють значні динамічно-вібраційні коливання. Описано доцільність дисперсного армування бетону та розглянуто різні види фібрового армування бетону з короткою характеристикою кожної 3 наведених фібр у праці [6]. В роботі зроблено висновки, щодо недостатню вивченість методів розрахунку фібробетону при різних впливах.

Надзвичайно актуальними для безпеки нашої держави є дослідженнями високоміцних фібробетонів. Оборонні споруди 3 такого матеріалу є дуже необхідними та затребуваними в зоні проведення АТО на сході України. Подібні дослідження в Україні вже почали проводитися [7, 8]. Високоміцні сталефібробетони та комбіновано армовані конструкції мають значно вищу в'язкість та тріщиностійкість в порівнянні з класичним залізобетоном при дії ударних динамічних навантаженнях (вплив енергії пробивання від снарядів).

Варто відмітити, що були виготовлені та проведені експериментальні дослідження придорожніх лотків водовідведення із сталефібробетону для автомобільних доріг, а також інженерних ливневих мереж. Основною метою роботи було встановити переваги та недоліки лотків із СФБ в порівнянні 3 типовими конструкційними рішеннями з бетону та залізобетону, що масово експлуатуються. Отримано суттєвий позитивний ефект. Детально ознайомитися 3 результатами проведених експериментальних досліджень лотків із сталефібробетону та отриманими висновками можна в працях [9-12].

Варто відмітити, що перед проведенням даного дослідження для підбору складу сталефібробетону було здійснено аналіз представлених на ринку будівельних матеріалів в Україні видів фібр для виготовлення фібробетонів. Значна увага була приділена сталевим анкерним і хвилястим фібрам (3 підвищеними механічними характеристиками) [13].

Самі поширені види фібр, що були проаналізовані під час проведення дослідження, представлені з їх основними характеристиками в табл. 1. 
Товарознавчий вісник. - 2018. - Випуск 11.

Таблиця 1

Загальний вигляд та геометричні розміри фібр для дисперсного армування

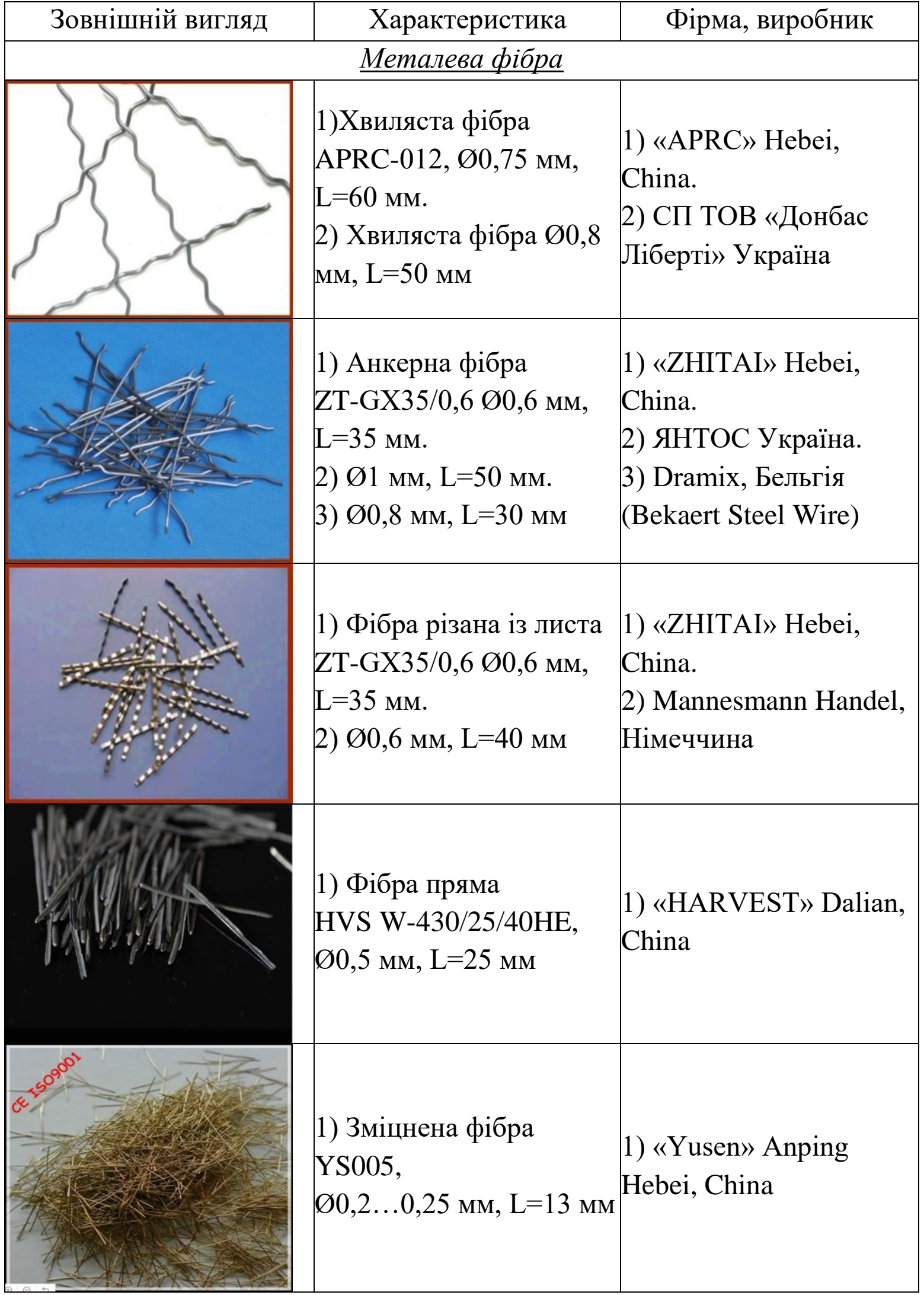


Товарознавчий вісник. - 2018. - Випуск 11.

Продовження таблиці 1

\begin{tabular}{|l|l|l|}
\hline \multicolumn{3}{|c|}{ Базальтова фібра } \\
\hline
\end{tabular}


Для отримання СФБ в якості дисперсного армування дослідних лотків застосовувалась хвиляста фібра діаметром 0,8 мм та довжиною 50 мм виробництва Українсько-Канадського СП ТОВ «Донбас Ліберті» згідно ТУ У В.2.7-28.7-00191046-015:2007 із параметрами згідно табл. 2.

Таблиця 2

\section{Геометричні розміри сталевих анкерних фібр}

\begin{tabular}{|c|c|c|c|}
\hline $\begin{array}{l}\text { Діаметр } \\
\text { фібри, } d\end{array}$ & $\begin{array}{c}\text { Довжина } \\
\text { фібри, } L \pm 2,0\end{array}$ & $\begin{array}{c}\text { Висота хвилі, } \\
h \text { не менше }\end{array}$ & $\begin{array}{c}\text { Крок хвилі, } \\
S \pm 1,5\end{array}$ \\
\hline MM & MM & MM & MM \\
\hline 0,8 & 50 & 1,0 & 8,3 \\
\hline
\end{tabular}

На рис. 1 показано загальний вигляд після розпалубки експериментальної партії лотків для водовідведення, що були виготовлені із сталефібробетону [13].

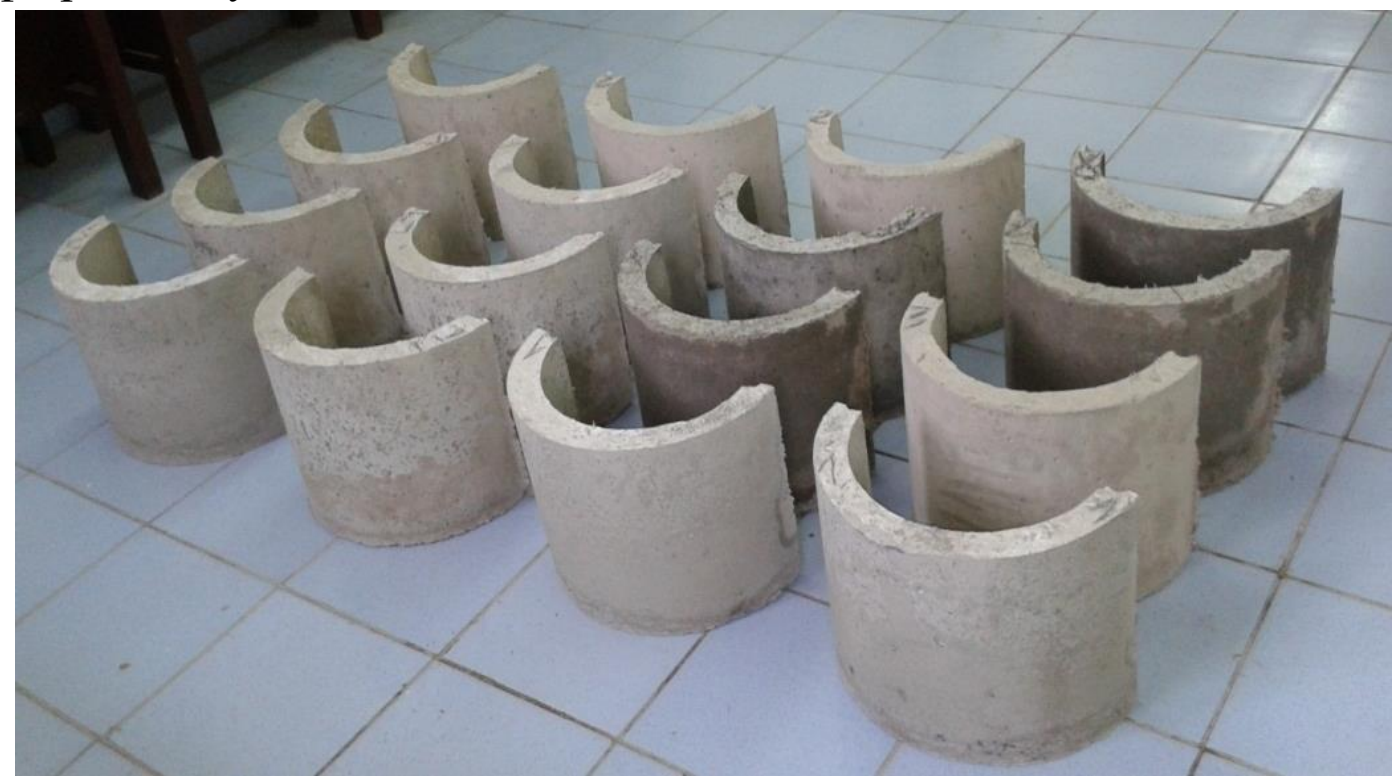

Рис. 1. Загальний вигляд лотків водовідведення після розпалубки

Дослідження сталефібробетонів $є$ затребуваним, актуальним та перспективним напрямком розвитку науки про будівельні конструкції. У 
даній статті проаналізовано характеристики найбільш поширених видів фібр, що необхідні для виготовлення дисперсних бетонів.

\section{Література}

1. Дорошенко О.Ю. Дисперсно-армований бетон - надійний та ефективний матеріал для транспортного будівництва / О.Ю. Дорошенко, Ю.М Дорошенко // Транспортное строительство Украины. - 2007. - № 5. - С. 16 - 20.

2. Гуйван Є.Ф. Високоефективні матеріали в будівництві автомобільних доріг і аеродромів / С.Ф. Гуйван, В.В. Харипончук, Ю.Ю. Зятюк // Ресурсоекономні матеріали, конструкції, будівлі та споруди. - 2017. - Вип. 34. - С. 24-32.

3. Бабич Є.М. Використання сталефібробетону для дорожньо-транспортних споруд / Є.М. Бабич, О.В. Андрійчук, С.О. Ужегов, І.М. Ясюк, Р.В. Шмігель // Містобудування та територіальне планування. - 2014. - Вип. 54. - С. 33-41.

4. Андрійчук О.В. Робота i розрахунок елементів кільцевого перерізу при дії повторних навантажень: Автореф. дис... канд. техн. наук: 05.03.21 / О.В. Андрійчук Львів, 2011. - 24 с.

5. Babych, E.M., Andriichuk, O.V. Strength of Elements with Annular Cross Sections Made of Steel-fiber-Reinforced Concrete Under One-Time Loads / E.M. Babych, O.V. Andriichuk // Materials Science, Vol. 52, No. 4, New York - 2017, p. 509 - 513.

6. Опанасенко Е.В. Виды фибрового армирования / Е.В. Опанасенко, А.А. Берестянская // Ресурсоекономні матеріали, конструкції, будівлі та споруди. - 2015. - Вип. 30. - C. 57-64.

7. Дворкін Л.Й. Високоміцні швидкотверднучі бетони та фібробетони: монографія / Л.Й. Дворкін, Є.М. Бабич, В.В. Житковський // Рівне: НУВГП, 2017. - 331 с.

8. Бабич Є.М. Дослідження опору високоміцних бетонів та фібробетонів пробиванню / Є.М. Бабич, Д.В. Кочкарьов, С.В. Філіпчук // Ресурсоекономні матеріали, конструкції, будівлі та споруди. - 2017. - Вип. 34. - С. 71-85.

9. Андрійчук О.В. Дослідження міцнісних характеристик сталефібробетонних лотків водовідведення / О.В. Андрійчук, І.М. Ясюк// Ресурсоекономні матеріали, конструкції, будівлі та споруди: Збірник наукових праць. - Рівне: НУВГП, 2015. - Випуск 31. - С. $371-378$.

10. Андрійчук О.В. Вплив короткочасних повторних навантажень на роботу сталефібробетонних лотків водовідведення / О.В. Андрійчук, І.М. Ясюк// Ресурсоекономні матеріали, конструкції, будівлі та споруди: Збірник наукових праць - Рівне: НУВГП, 2016. - Випуск 32. - С. 113 - 120.

11. Ясюк І.М. Тріщиностійкість сталефібробетонних лотків при дії одноразових короткочасних навантажень / I.M. Ясюк// Сучасні технології та методи розрахунків у будівництві: Збірник наукових праць - Луцьк: РВВ Луцького НТУ, 2015. - Випуск 4. - С. $248-255$.

12. Андрійчук О.В. Виготовлення придорожніх лотків водовідводу зі сталефібробетону / О.В. Андрійчук, І.М. Ясюк// Наукові нотатки: Збірник наукових праць Луцьк: РВВ Луцького НТУ, 2014. - Випуск 45. - С. 7 - 14.

Цель. Проанализировать виды фибр для дисперсно-армированных бетонов, которые сегодня представлены на рынке строительных материалов. Охарактеризовать их недостатки и преимущества. Особое внимание уделить стальньм фибрам, что применяются во время производства сталефибробетона.

Методика. Во время проведения исследования использовались предусмотренные 
действующими государственными стандартами методы, которые позволяют определить механические свойства железобетонных и сталефибробетонных конструкиий.

Результаты. Проанализировав сферы применения железобетонных конструкций во время строительства инженерных сооружений, рекомендуется применять во время их изготовления дисперсно-армированные бетоны. Во время проведения исследований установлено, что при введении в бетон стальных фибр, значительно увеличивается его жесткость, что в свою очередь приводит к повышению деформативности от действия нагрузок и трещиностойкости сталефибробетона, как материала. $B$ статье рассмотрены различные виды фибрового армирования бетона. Представлено краткую характеристику каждого из видов фибр, что представлены на рынке строительных материалов Украиныл.

Научная новизна. Описана целесообразность дисперсного армирования бетона во время изготовления инженерных конструкиий. Сделаны выводы относительно недостаточного изучения методов расчета фибробетона при различных воздействиях.

Практическая значимость. Результаты проведенных научных исследований могут быть использованы во время проектирования и строительства дорожно-транспортных сооружений из сталефибробетона на автомобильных дорогах, подвергающихся действию значительных динамических воздействий.

Ключевые слова: железобетон, сталефибробетон, СФБ, фибра, водоотвод, лоток, прочность, трещиностойкость.

Purpose. Analysis of existing fiber types for dispersion-reinforced concrete that is represented on the market of construction materials. Describing their advantages and disadvantages. Paying particular attention to the steel fibers that are used during the manufacture of steel fiber reinforced concrete.

Methodology. During conducting of the research it was used acting regulatory methods of national standards which allow to determine the mechanical properties of reinforced concrete and steel fiber reinforced concrete constructions.

Findings. After analyzing the scope of reinforced concrete constructions during the construction of engineering structures, it is recommended to use dispersion-reinforced concrete for their manufacture. During research it is established that adding of steel fibers to the concrete significantly increases its rigidity, which in turn leads to an increase of deformation from the loads and fracture toughness of steel fiber reinforced concrete. In the article the various types of fiber reinforcement of concrete are described. It is presented a brief description of each types of fibers that are available on the market of building materials in Ukraine.

Originality. In the article it is described the feasibility of the disperse concrete reinforcement during the manufacture of engineering structures. It was concluded that the insufficient study of calculation methods of fiber reinforced concrete with different effects.

The practical value. The results of scientific research can be used during the design and construction of steel fiber reinforced concrete road structures on highways that are exposed to significant dynamic effects.

Keywords: reinforced concrete, steel fiber reinforced concrete, SFRC, fiber, water diversion, road gutter, durability, fracture toughness.

Рекомендовано до публікації д.т.н. професором Луиьккого НТУ Шваб'юком В.І. Дата надходження в редакиію 30.01.2018 р. 